\title{
Evaluation of allicin stability in processed garlic of different cultivars
}

\author{
Patricia PRATI ${ }^{1 *}$, Celina Maria HENRIQUE ${ }^{1}$, Aparecida Sônia de SOUZA², \\ Vera Sônia Nunes da SILVA², Maria Teresa Bertoldo PACHECO²
}

\begin{abstract}
This research aimed at evaluating the suitability of five different garlic cultivars for the processing of unsalted garlic paste, chopped fried garlic, and fried sliced garlic. The concentration of allicin in the products was evaluated immediately after processing and at 45-day intervals during 180 days of storage. Allicin concentrations in raw garlic of the varieties under study differed (20.73 a $24.31 \mathrm{mg}$ of allicin $\mathrm{g}^{-1}$ garlic). Stability exhibited a similar between the varieties according to the type of processing utilized. Processing into paste was more favorable to the preservation of allicin than the other processes. The amount of allicin lost during the process to obtain paste for the different varieties was less than $9.5 \%$, and it reached a maximum loss of $22 \%$ for the commercial varieties during storage (180 days). All fried garlic samples showed a decrease by $99 \%$ in the content of allicin right after processing. The processing of garlic in the form of acidified paste preserved its bioactive characteristics during storage.
\end{abstract}

Keywords: bioactive compounds; allicin stability; Allium sativum L.; garlic fried; garlic paste.

\section{Introduction}

Garlic (Allium sativum L.) occupies a prominent position among human foods, not only as a condiment, but also due to its therapeutic properties, attributed to the presence of bioactive compounds (Tepe et al., 2005). Garlic is a bulb from the Liliacerae family and is widely consumed all over the world. Its beneficial properties have been recognized for over 5000 years (Amagase et al., 2001). It is indicated as an adjuvant agent in the therapy for prevention of various chronic infirmities such as heart diseases, infections, and atherosclerosis. Most of garlic's health benefits have been attributed to the antioxidant activity of organosulfurous compounds, predominantly allicin (Queiroz et al., 2009; Rahman \& Lowe, 2006).

Garlic is the food with the highest number of organosulfurous compounds. Thirty-three of these compounds have been identified, and the biological activity of several is known. On average, $1 \mathrm{~g}$ of fresh garlic contains 11 to $35 \mathrm{mg}$ of total organosulfurous compounds, representing a level approximately four times greater (per gram of fresh weight) than that of other sources such as onions, broccoli, cauliflower, turnip, cabbage and other crucifers (Holub et al., 2002).

The peculiar characteristic of garlic, which promotes its use in cooking, is its pungent aroma, released primarily during handling or processing. Intact garlic cells contain (+)-S-allylL-cysteine sulfoxide, an odorless compound known as alliin. When cell lysis occurs, the enzyme alliinase stored in vacuoles inside the cells are released, and when they come in contact with alliin, they are converted into allicin (diallyl thiosulfinate). Allicin decomposes in the presence of air and water producing mainly diallyl disulfides (responsible for the characteristic odor of garlic). This same degradation process occurs in the body, and it is associated with the characteristic odor in breath after garlic ingestion (Gómez \& Sánchez-Muniz, 2000).
Although considered non-nutritive, the compounds formed from the decomposition of alliin play an important role in the diet as antioxidants, protecting against certain degenerative diseases, and acting as a potent antibacterial against positive and negative gram bacteria (Okada et al., 2006). They also act as antimicrobials agent against the Helicobacter pylori bacterium, which may cause damages to the gastric mucosa of the stomach, sometimes resulting in gastric and duodenal ulcers, leading to the emergence of cancer (Sivam, 1997).

As far as cardiovascular disease is concerned, studies show that the active compounds of garlic prevent cholesterol from attaching itself to the walls of blood vessels. It has been shown that garlic's bioactive compounds act by increasing the elasticity of blood vessels and by relaxing small muscles around them. Furthermore, the compounds in garlic have the ability to reduce fats, particularly LDL-cholesterol (Chen et al., 2008; Kojuri et al., 2007; Rahman \& Lowe, 2006).

A WHO (World Health Organization, 2010) monograph on medicinal plants commonly used in the Newly Independent States (NIS) makes the following daily intake recommendation: 2-5 $\mathrm{g}$ of fresh garlic, 0.4 to $1.2 \mathrm{~g}$ of dry powdered garlic, 2 to 5 $\mathrm{mg}$ of oil, and 0.3 to $1 \mathrm{~g}$ of dry extract. The American Dietetic Association (American Dietetic Association, 2004) recommends the consumption of 600-900 mg of garlic per day in a regular diet or as a dietary supplement. However, it is important to note that the U.S. Food and Drug Administration has not approved the use of garlic (or its derivatives) as cholesterol-lowering agent.

The type and concentration of bioactive compounds extracted from garlic depend on a set of variables including the cultivar, stage of maturation, crop production practices, location, and finally processing conditions. Obtaining essences and extracts from dehydrated, canned, or frozen garlic may lead 
to the formation of products with different physicochemical and biological properties. In addition to alliin, garlic extract contains seven other thiosulfinates which constitute $20-40 \%$ of total thiosulfinates. These compounds are highly reactive in the presence of sulfhydryl compounds (Gómez \& SánchezMuniz, 2000).

It is acknowledged that the instability of allicin found in the chemical and biological analyses can be, among other factors, due to chemical changes that occur in the molecule. The ability of forming allicin is reduced not only by the disruption of cellular structures, but also due to the shrinkage of these compartments, which was confirmed by the evaluation of these levels during storage of healthy bulbs (Lagunas \& Castaigne, 2008). Hugues et al. (2006) compared the storage of garlic at room temperature and under refrigeration $\left(4^{\circ} \mathrm{C}\right)$ for a period of 6 months. Various aroma precursors were evaluated, and some sulfur compounds (alliin, isoallina, $\delta$-glutamyl cysteine allyl sulfoxide) did not show statistical differences in the alliin content under different storage conditions.

For processed foods, the procedure has great influence on preservation of bioactive compounds of garlic, especially those related to antioxidant activity, such as that performed by allicin from garlic. Therefore, the antioxidant activity of several varieties of dehydrated freeze-dried garlic was measured and compared the results of fresh garlic. It was concluded that the process used to freeze-dry garlic at low temperatures did not alter the concentrations of antioxidants and the activity of allicin (Silva et al., 2010).

Studies have shown the influence of home cooking methods (boiling, microwaving, pressure-cooking, griddling, frying, and baking) on the antioxidant activity of vegetables. Twenty different vegetables (including garlic) have been evaluated using different antioxidant activity assays. All methods showed significant losses on the antioxidant activity of garlic (JiménezMonreal et al., 2009).

The bioactive compounds and antioxidant activity of raw $(\mathrm{RG})$, boiled (BG) and fried garlic (FG) have been evaluated. Total phenolic compounds, flavonoids, allicin, and phytosterol have also quantified. The thermal processing of RG decreased its bioactive compounds and antioxidant capacity. Boiling was found to be less aggressive than frying, and strong correlations were obtained between total phenolic compounds and the antioxidant assays. The authors concluded that RG and BG should be preferred for human consumption as they present higher antioxidant capacity (Queiroz et al., 2014).

Since allicin is extremely unstable due the presence of free thiol groups, the aim of this study was to evaluate the effect of processing and storage on the degradation of this bioactive compound in different garlic cultivars and the intake of sufficient amounts of garlic to meet the recommended daily amounts mentioned above. Therefore, the processes for obtaining saltfree acidified garlic paste, sliced garlic and chopped garlic fried in vegetable fat were selected.

Different garlic cultivars were used to validate the technological process applied and the stability during storage. To this end, the study included national and imported cultivars of relevance to Brazilian agribusiness.

\section{Materials and methods}

\subsection{Materials}

Five cultivars of garlic were used in the study. A Chinese cultivar named "Comercial", for the purpose of this study, belonging to Roxo group and Noble subgroup, was purchased from local market. Four Brazilian semi-noble cultivars named Assai, Gigante de Curitibanos (Gigante), Santa Catarina Roxo (SC Roxo), and Roxinho were obtained from the Research and Development Unit of "APTA Polo Centro Sul" in the municipality of Tietê (São Paulo, Brazil).

Citric acid anhydrous (>99.5\%) and potassium sorbate (Vetec $^{\mathrm{mt}}>98 \%$ ) were purchased from SigmaAldrich (France) and Synth company (Synth brand, Labsynth, Diadema - SP, Brazil), respectively. The solvents used were of analytical and HPLC grade.

\subsection{Salt-free acidified paste processing}

The raw bulbs were manually peeled after immersion in water at room temperature for 30 minutes. Thus, the samples were processed into garlic paste, fried sliced garlic (using a PROGRESSIVE manual slicer, São Paulo, Brazil), and chopped fried garlic (using a MAX MACHINE stainless steel cutter with the capacity for $4 \mathrm{~kg}$ per batch, model CUT-4, São Paulo, Brazil), as shown in Figure 1.

Garlic bulbs were crushed using a stainless steel industrial blender and subsequently mixed with $50 \%$ of water (based on the garlic weight) to help homogenization. The paste freshness color were preserved with the addition of $0.1 \%$ potassium sorbate and 2\% citric acid (dry), respectively, based on the total mass. Preliminary assays were carried out to determine the ideal amount of citric acid, and the concentration necessary for the paste to reach $\mathrm{pH}<4.0$, helping maintaining the natural light color of the product was chosen as the selection criteria.

After processing, the garlic products obtained were placed in $200 \mathrm{~g}$-plastic containers and stored at controlled temperature of $25^{\circ} \mathrm{C} \pm 2^{\circ} \mathrm{C}$, simulating room temperature, for a period of 180 days.

\subsection{Physicochemical characterization}

Approximate centesimal composition analysis was performed in the different cultivars in the raw form and immediately after processing (time zero), in accordance with Horwitz (2010).

\subsection{Determination of allicin}

Allicin concentration was determined in the raw garlic and processed products of the different cultivars. In the processed products (unsalted garlic paste, chopped fried garlic, and fried sliced garlic), the analysis was performed immediately after processing (zero time) and, thereafter, every 45 days of storage over 180 days. The INA method 110.001 of the Institute for Nutraceutical Advancement (National Sanitation Foundation \& Internacional, Institute for Nutraceutical Advancement, 2005) was used. 


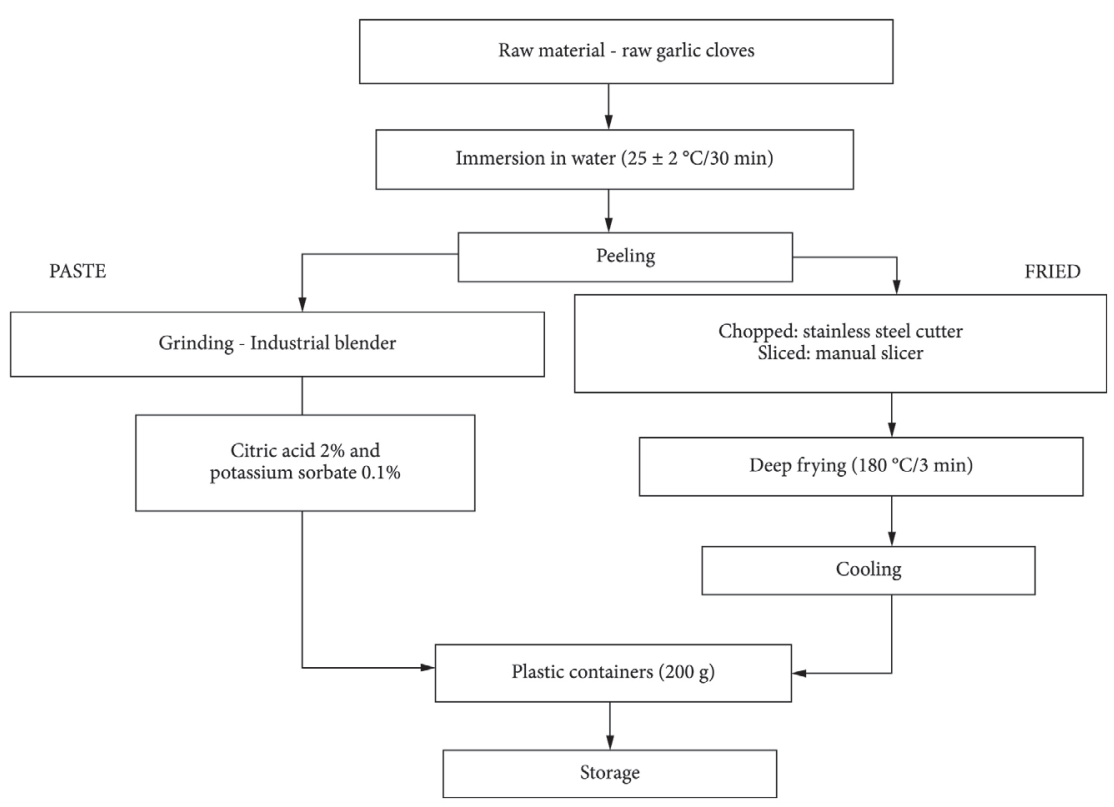

Figure 1. Processing diagram of garlic paste, chopped garlic, and fried sliced garlic.

Allicin standard preparation: Allicin was extracted by mixing $400 \mathrm{mg}$ of fresh garlic with $10 \mathrm{~mL}$ of water and shaking for $2 \mathrm{~min}$. Solid phase extraction (SPE) procedure was followed to obtain purified allicin from the aqueous extract from garlic. A C18 SPE cartridge (SPE C18E 1g/6mL cartridge, Phenomenex/ $8 \mathrm{BS} 001 \mathrm{JCH}$ ) was used. The SPE column was rinsed with $6 \mathrm{~mL}$ of methanol and then conditioned with three column volumes $(18 \mathrm{~mL})$ of mobile phase (methanol:water 50:50). Elution of allicin was performed using the same mobile phase (methanol: water) and collected.

The concentration of allicin in the isolated fraction was standardized by spectrophotometry, according to the HPLC analysis. The absorbance of the collected fraction was measured at $240 \mathrm{~nm}$ and $254 \mathrm{~nm}$ using a $1 \mathrm{~cm}$ quartz cuvette. Tipically, the absorbance ratio $(240 \mathrm{~nm} / 254 \mathrm{~nm})$ is 1.4 to 1.5 .

The chromatographic purity was used as an acceptance criterion for the calibration solution, and the percentage of impurity per peak area should be less than $12 \%$ for the allicin solution to be used as a standard.

The working standard was diluted with water to create standards for a linearity curve covering approximately $5-80$ $\mu \mathrm{g} / \mathrm{mL}$ for HPLC analysis. The standard temperature was maintained cold, and they were stored at $\leq 0^{\circ} \mathrm{C}$ until use.

Sample preparation: to prepare the aqueous extract from the garlic samples, $0.7-0.9 \mathrm{~g}$ of samples were weighed and added to $25 \mathrm{~mL}$ of chilled water $\left(4^{\circ} \mathrm{C}\right)$, stirred vigorously for 30 seconds; an extra $25 \mathrm{~mL}$ of cold water were added and it was stirred for 30 more seconds. The samples were filtered through a $0.45 \mu \mathrm{m}$ filter membrane for HPLC analysis. The samples were quantified against the isolated allicin external standard using a calibration curve.

The analyses were conducted using a high performance liquid chromatograph with a reversed-phase column containing an LC 300psi gradient pump equipped with a degasifier (DGU-M10A), micro-valve injector, and a Shimadzu SPDM10A diode array detector with a wavelength of $240 \mathrm{~nm}$ and a LC-18 reversed-phase column (Prodigy $5 \mu$ ODS3 $100 \AA 250 \times 4,6 \mathrm{~mm}$, Phenomenex/4097E0), operating at the temperature of $28 \pm 0.5^{\circ} \mathrm{C}$. The mobile phase consisted of methanol and water (50:50) and flow rate of $1.0 \mathrm{ml} / \mathrm{min}$. The total running time was $20 \mathrm{~min}$.

\subsection{Statistical analysis}

The means were analyzed using a completely randomized design, with SAS INSTITUTE (Statistical Analisys System Institute, 1993) software; the analysis of variance (ANOVA) and the Tukey mean tests at a 5\% significance level were used.

\section{Results and discussion}

The amount of alliin is an important criterion for assessing the quality of the different commercial varieties of garlic since it is directly related to the state of freshness and appropriate conservation techniques. This compound represents about $70 \%$ of fresh garlic sulfur compounds. In the edible portion of garlic, Alliin is confined to cell vacuoles and protected from the action of alliinase enzyme found in the cytoplasm. Therefore, the enzymes have access to the substrate only upon handling, when the tissue is broken resulting in the formation of allicin accompanied by the release of the characteristic garlic aroma (Holub et al., 2002).

The centesimal composition of the different garlic varieties and the values of the just-processed paste and the frying processes are shown in Table 1. The lowest concentration of lipid fraction was found in the raw garlic and the salt-free acidified paste, whereas the highest concentration was found in the products resulting from the frying process. 
Table 1. Centesimal composition $(\mathrm{g} / 100 \mathrm{~g})$ of the garlic cultivars in raw form and in the following products: just-processed paste (zero storage time) and fried sliced and chopped garlic, on a dry basis (d.b.* $)^{* *}$.

\begin{tabular}{|c|c|c|c|c|c|}
\hline Samples & Total Solids & Protein & Lipids & Ash & Carboydrates \\
\hline \multicolumn{6}{|c|}{ Raw garlic } \\
\hline Roxinho & $31.82 \pm 0.34^{b c}$ & $16.28 \pm 0.10^{\mathrm{b}}$ & $0.66 \pm 0.02^{\mathrm{b}}$ & $3.35 \pm 0.01 \mathrm{bc}$ & $11.53 \pm 0.34^{\mathrm{ab}}$ \\
\hline SC Roxo & $30.62 \pm 0.28^{c}$ & $19.82 \pm 0.03^{\mathrm{a}}$ & $0.82 \pm 0.01^{\mathrm{a}}$ & $3.82 \pm 0.23^{b}$ & $6.16 \pm 0.19^{c}$ \\
\hline Assai & $33.07 \pm 0.18^{\mathrm{ab}}$ & $16.96 \pm 0.12 \mathrm{ab}$ & $0.57 \pm 0.00^{c}$ & $3.45 \pm 0.09^{\mathrm{bc}}$ & $12.09 \pm 0.36^{\mathrm{ab}}$ \\
\hline Gigante & $34.59 \pm 0.43^{\mathrm{a}}$ & $15.81 \pm 0.10^{c}$ & $0.49 \pm 0.00^{\mathrm{d}}$ & $2.96 \pm 0.09^{c}$ & $15.33 \pm 0.54^{\mathrm{a}}$ \\
\hline Comercial & $33.19 \pm 1.38^{\mathrm{ab}}$ & $15.31 \pm 0.06^{c}$ & $0.84 \pm 0.02^{\mathrm{a}}$ & $4.38 \pm 0.25^{\mathrm{a}}$ & $12.66 \pm 1.67 \mathrm{ab}$ \\
\hline \multicolumn{6}{|c|}{ Garlic Paste } \\
\hline Roxinho & $30.47 \pm 0.05^{\mathrm{a}}$ & $14.60 \pm 0.07^{\mathrm{b}}$ & $0.23 \pm 0.00^{c}$ & $8.27 \pm 2.09^{\mathrm{a}}$ & $7.37 \pm 2.15^{\mathrm{b}}$ \\
\hline SC Roxo & $27.29 \pm 0.11^{\mathrm{a}}$ & $16.53 \pm 0.09^{\mathrm{a}}$ & $0.22 \pm 0.00^{c}$ & $6.59 \pm 0.56^{\mathrm{ab}}$ & $3.95 \pm 0.44^{c}$ \\
\hline Assai & $36.05 \pm 14.45^{\mathrm{a}}$ & $12.23 \pm 0.10^{\mathrm{c}}$ & $0.50 \pm 0.01^{b}$ & $2.51 \pm 0.53^{c}$ & $20.81 \pm 14.22^{a}$ \\
\hline Gigante & $27.20 \pm 0.03^{\mathrm{a}}$ & $15.04 \pm 0.03^{\mathrm{a}}$ & $0.51 \pm 0.00^{\mathrm{b}}$ & $3.82 \pm 0.21^{c}$ & $7.83 \pm 0.22^{b}$ \\
\hline Comercial & $26.08 \pm 0.09^{\mathrm{a}}$ & $13.88 \pm 0.03^{c}$ & $0.58 \pm 0.01^{\mathrm{a}}$ & $6.83 \pm 1.01^{\mathrm{ab}}$ & $4.79 \pm 0.96^{c}$ \\
\hline \multicolumn{6}{|c|}{ Fried chopped garlic } \\
\hline Roxinho & $90.72 \pm 0.21^{\mathrm{bc}}$ & $12.15 \pm 0.03^{b}$ & $29.06 \pm 0.46^{d}$ & $3.18 \pm 2.58^{\mathrm{bc}}$ & $46.33 \pm 2.41^{\mathrm{ab}}$ \\
\hline SC Roxo & $89.41 \pm 0.63^{c}$ & $13.06 \pm 0.10^{\mathrm{a}}$ & $29.28 \pm 0.28^{\mathrm{d}}$ & $3.64 \pm 4.05^{b}$ & $43.43 \pm 3.77^{b}$ \\
\hline Assai & $95.95 \pm 2.18^{\mathrm{a}}$ & $11.34 \pm 0.06^{c}$ & $33.31 \pm 0.44^{\mathrm{b}}$ & $3.34 \pm 2.91 \mathrm{bc}$ & $47.96 \pm 4.65^{\mathrm{a}}$ \\
\hline Gigante & $96.74 \pm 0.08^{\mathrm{a}}$ & $11.05 \pm 0.01^{\mathrm{c}}$ & $35.66 \pm 0.15^{a}$ & $2.72 \pm 2.35^{c}$ & $47.31 \pm 2.34^{\mathrm{a}}$ \\
\hline Comercial & $92.73 \pm 0.31^{\mathrm{b}}$ & $11.43 \pm 0.20^{c}$ & $32.74 \pm 0.11^{c}$ & $4.14 \pm 3.31^{\mathrm{a}}$ & $44.42 \pm 3.41^{\mathrm{b}}$ \\
\hline \multicolumn{6}{|c|}{ Fried sliced garlic } \\
\hline Roxinho & $92.27 \pm 0.86^{c}$ & $12.38 \pm 0.02^{\mathrm{b}}$ & $25.78 \pm 0.06^{\mathrm{e}}$ & $3.31 \pm 1.61^{b c}$ & $50.80 \pm 1.82^{\mathrm{b}}$ \\
\hline SC Roxo & $92.59 \pm 0.99^{c}$ & $14.14 \pm 0.06^{\mathrm{a}}$ & $26.88 \pm 0.41^{\mathrm{d}}$ & $3.33 \pm 0.66^{b}$ & $48.24 \pm 1.30^{c}$ \\
\hline Assai & $98.36 \pm 0.12^{\mathrm{a}}$ & $12.40 \pm 0.07^{\mathrm{b}}$ & $30.19 \pm 0.34^{\mathrm{a}}$ & $3.20 \pm 2.78^{b c}$ & $52.57 \pm 2.50 \mathrm{ab}$ \\
\hline Gigante & $96.77 \pm 0.77 \mathrm{ab}$ & $10.66 \pm 0.46^{\mathrm{d}}$ & $28.19 \pm 0.04^{b}$ & $2.83 \pm 2.51^{c}$ & $55.09 \pm 2.05^{\mathrm{a}}$ \\
\hline Comercial & $95.67 \pm 2.02^{\mathrm{b}}$ & $11.72 \pm 0.05^{\mathrm{c}}$ & $27.23 \pm 0.01^{\mathrm{c}}$ & $4.04 \pm 1.44^{\mathrm{a}}$ & $52.68 \pm 0.85^{\mathrm{ab}}$ \\
\hline
\end{tabular}

${ }^{*}($ d.b. $)=$ results expressed on dry basis; ${ }^{* *}$ means followed by the same capital letter in the same column did not differ at $\mathrm{p}<0.05$.

Since garlic is used as a condiment in meal preparation in relatively small amounts, its nutritional contribution is relatively insignificant.

The composition of just-processed garlic paste (Table 1), obtained according to the flowchart in Figure 1, shows that there was a decrease in total solids content and consequently in the concentrations of the other components with the exception of ash. This increase was probably caused by the addition of $2 \%$ citric acid, which may have contributed to the formation of citrate salts.

The total solid result of fried chopped and sliced garlics shows (Table 1) that there was a great water loss, which was partially replaced by the fat used for frying. Probably, it caused an increase in lipid and ash content and consequently in the total solids of the fried products.

The method used for allicin determination is a high sensitivity method established by NSF INTERNATIONAL (National Sanitation Foundation \& Internacional, Institute for Nutraceutical Advancement, 2005). Table 2 shows the allicin content determined in the raw material and just-processed products (time zero) using different processing techniques.

The determination of allicin is complex because of its highly reactive and unstable nature. The half-life of allicin can vary depending on the concentration, temperature, extraction solvent, and storage, which may have explain some of the different results reported in the literature. The conversion of alliin into allicin is fast and complete; it takes less than 10 seconds in raw garlic at $23^{\circ} \mathrm{C}$.

The allicin levels of fresh garlic obtained in this study ranged from 6.34 to $7.74 \mathrm{mg} . \mathrm{g}^{-1}$ (w.b.), which are higher than those reported by Ribak et al. (2004), who used supercritical fluid extraction. In their study, allicin content corresponded to 3.37 to $4.60 \mathrm{mg} \cdot \mathrm{g}^{-1}$ of the overall weight of the edible part of fresh garlic. The method used in the present study involves some critical factors which may result in differences in the values of allicin. These factors include homogenization, time between extraction and injection of the sample in the HPLC, and low temperature extraction to ensure that the enzyme remains active during allicin formation and to prevent its degradation into other sulfur compounds. The allicin used as external standard (HPLC) was obtained by solid phase extraction of solutions containing allicin, at the laboratory. The incomplete extraction of the allicin standard sample can affect the absorbance value obtained for calculation of the concentration of different samples, but this variable was considered constant in all samples. Therefore, the differences in the results may be attributed to various external factors including: temperature, time taken in the processing steps of the method, stirring of the solutions, volatilization of allicin, garlic ripeness, and amount of allicin in the bulb varieties evaluated in this study. It is important to note that all variables were rigorously monitored to avoid interference in the analysis results.

Allicin values in raw garlic ranging from 4.30 to $8.99 \mathrm{mg} . \mathrm{g}^{-1}$ were found by other authors (Silva et al., 2010; Lawson et al., 
Table 2. Means and standard deviations of allicin levels (dry basis) in raw garlic of different cultivars: garlic paste, fried chopped garlic, and fried sliced garlic**.

\begin{tabular}{|c|c|c|c|c|}
\hline \multicolumn{5}{|c|}{ Allicin concentration $\left(\mathrm{mg} \cdot \mathrm{g}^{-1}\right)^{*}$} \\
\hline Variety & Raw garlic & Garlic paste & Fried chopped garlic & Fried sliced garlic \\
\hline Roxinho & $24.31 \pm 0.27^{\mathrm{A}}$ & $23.53 \pm 0.13^{\mathrm{A}}$ & $0.32 \pm 0.00^{\mathrm{A}}$ & $0.32 \pm 0.01^{\mathrm{A}}$ \\
\hline SC Roxo & $20.73 \pm 0.11^{\mathrm{D}}$ & $19.32 \pm 0.02^{\mathrm{D}}$ & $0.17 \pm 0.00^{\mathrm{D}}$ & $0.16 \pm 0.00^{\mathrm{D}}$ \\
\hline Gigante & $21.98 \pm 0.11^{\text {в }}$ & $20.35 \pm 0.31^{\text {в }}$ & $0.28 \pm 0.01^{\text {в }}$ & $0.29 \pm 0.00^{\mathrm{B}}$ \\
\hline Assaí & $21.73 \pm 0.02^{\mathrm{C}}$ & $19.78 \pm 0.05^{\mathrm{C}}$ & $0.29 \pm .0 .00^{\mathrm{B}}$ & $0.29 \pm 0.00^{\mathrm{B}}$ \\
\hline Comercial & $20.79 \pm 0.02^{\mathrm{D}}$ & $18.61 \pm 0.24^{\mathrm{E}}$ & $0.22 \pm 0.00^{\mathrm{C}}$ & $0.19 \pm 0.01^{\mathrm{C}}$ \\
\hline
\end{tabular}

${ }^{\star}$ results expressed on dry basis; ${ }^{* *}$ means followed by the same capital letter in the same column did not differ at $\mathrm{p}<0.05$.

1991). The values are comparable to those found in this study, when the mass of fresh garlic is considered. The values of allicin in the raw garlic found in this study (expressed in wet weight) for the different samples ranged from 6.34 to $7.74 \mathrm{mg} \cdot \mathrm{g}^{-1}$ $(\mathrm{p}<0.05)$. Such variations are due to parameters such as garlic grinding, varietal and crop differences, and the drying process after harvest, which are factors that interfere in the formation of allicin produced from the interaction of alliin (a non-protein amino acid) with the enzyme alliinase (Baghalian et al., 2005; Gómez \& Sánchez-Muniz, 2000; Holub et al., 2002). Roxinho variety showed the highest value $\left(24.31 \mathrm{mg} \cdot \mathrm{g}^{-1}\right)$, while SC Roxo showed the lowest $\left(20.73 \mathrm{mg} \cdot \mathrm{g}^{-1}\right)$, in dry basis. The amounts of allicin are expressed on a dry basis to facilitate comparison of products with different moisture contents.

As expected, fried garlic samples lost all amounts of allicin immediately after the frying process, showing that this process causes degradation of its beneficial health components. Loss levels reached $99 \%$ for all samples, probably as a result of oxidation and denaturation of bioactive sulfur compounds.

Although concentrations of allicin varied in the different varieties, there was no significant loss of the initial content in the raw garlic during the acid paste. Processing, The allicin concentrations found in the fresh garlic and immediately after processing (time zero) reveal that the pastes had an allicin loss of less than $10 \%$ (3.2\% for the Roxinho variety, $6.8 \%$ for SC Roxo, 7.4\% for Gigante; and 8.9\% for Assaí and 9.5\% for Comercial). These values partly reflect the reduction in the dry solid content of the pastes and show that the conditions selected for the process were probably mild and did not significantly affect this compound.

It has been pointed out that the instability of allicin found in the chemical and biological analyses may be due to chemical changes that occur in the molecule, among other reasons. The stability results of allicin in the acid garlic pastes of different cultivars as a function of storage time are shown in Figure 2.

The values obtained in this study suggest that the saltfree acidified paste process proposed preserved the sulfur components and ensured the stability of the product during storage, independent of the raw material used.

The comparison of the cultivars among themselves shows that the pastes of Roxinho, Gigante and Assaí and their corresponding raw materials (Table 2) showed higher values of allicin ( $p \leq 0.05)$ during the entire evaluation. On the other hand, the Commercial garlic paste, for which shelf life of bulb was not controlled before processing, had lower values, which

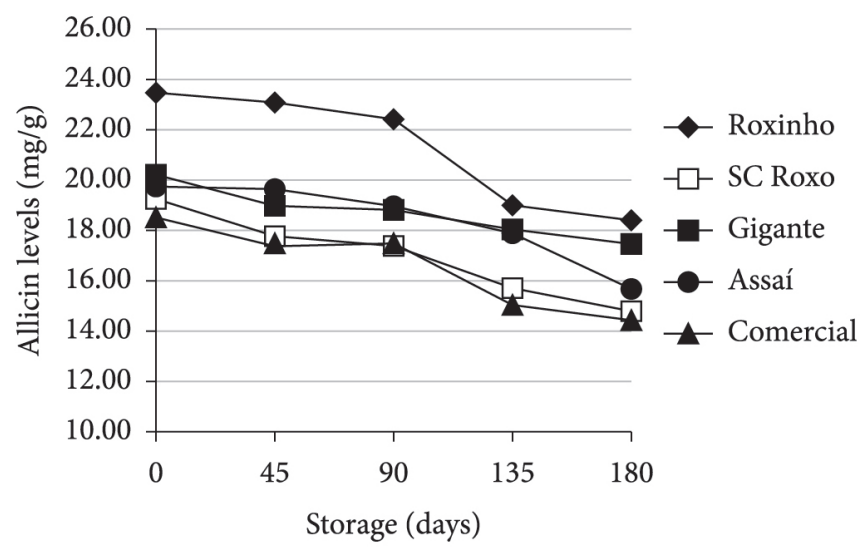

Figure 2. Means and standard deviations of allicin levels $\left(\mathrm{mg} \cdot \mathrm{g}^{-1}\right)$, on a dry basis, in acid garlic pastes from different cultivars over 180 days of storage.

may be attributed to the dehydration and shrinkage of cellular compartments.

Allicin decreased gradually in the garlic paste in all cultivars evaluated, at the end of storage of 180 days; the losses were approximately $21 \%$ for the Brazilian varieties and for the "Commercial" cultivar evaluated. Since there was breakage in the plant compartments under the conditions of the processing methods and since allicin is a highly reactive compound due to the presence of sulfhydryl, reactions with other components of the system probably occurred, leading to structure changes and decomposition during storage at room temperature.

Moreover, the allicin values in the paste in the final period of storage (180 days), on a wet basis, (7.74 mg.g ${ }^{-1}$ in Roxinho, $6.34 \mathrm{mg} \cdot \mathrm{g}^{-1}$ in SC Roxo, $7.60 \mathrm{mg} \cdot \mathrm{g}^{-1}$ in Gigante, $7.19 \mathrm{mg} \cdot \mathrm{g}^{-1}$ in Assaí, and $6.90 \mathrm{mg}^{-1} \mathrm{~g}^{-1}$ in Comercial) were next to the values found by Lawson et al. (1991) for the raw garlic ( $4.30 \mathrm{mg} \cdot \mathrm{g}^{-1}$ to $6.36 \mathrm{mg} . \mathrm{g}^{-1}$ ) of some Chinese varieties. Thus, this result confirms that the salt-free acidified paste process preserves, in a certain way, the sulfur components and ensures the stability of the product during storage, independent of the raw material used.

With regard to processed foods, the procedure used has a major influence on the preservation of the bioactive compounds, mainly those related to antioxidant activity such as allicin in garlic. This fact has been clearly demonstrated in various studies, Hugues et al. (2006), Silva et al. (2010), Queiroz et al. (2014). 
The concentration of allicin at the end of storage was associated to the processing type and temperature. The acidified paste prepared under the conditions previously mentioned in this study showed significant allicin retention after 180 days of storage. Regarding the concentration of allicin in the product after this time period, it would be necessary to ingest 1.5 to $2.0 \mathrm{~g}$ of paste to reach the WHO-recommended daily amount of allicin (World Health Organization, 2010). However, like it occurred in the frying process in which allicin decomposed, probably because of temperature, it is important to emphasize that there may have been further losses of this compound due to the conditions of food preparation regarding handling and preparation of the product.

\section{Conclusions}

The levels of allicin found in the raw materials are similar of those reported in the literature, evidencing adequate allicin extraction and handling of the samples. Processing garlic into an acidified paste had little effect on the allicin content of raw garlic, with a slight reduction in concentration during storage. Frying garlic process, regardless of the way that the sample was cut, resulted in allicin loss; this bioactive compound was not detected in the samples after 45-days of storage.

Thus, this study shows that garlic (Allium sativum L.), both in raw form and as acidified paste, has a bioactive component, allicin, which has potential health benefits.

\section{Acknowledgements}

The authors would like to thank the Research Foundation of the State of São Paulo (FAPESP) for the financial support.

\section{References}

Amagase, H., Petesch, B. L., Matsuura, H., Kasuga, S., \& Itakura, Y. (2001). Intake of garlic and its bioactive components. Journal of Nutrition, 131(3s), S955-S962.

American Dietetic Association - ADA. (2004). Position of the American Dietetic Association: functional foods. Journal of American Dietetic Association, 104(5), 814-826. PMid:15127071. http://dx.doi. org/10.1016/j.jada.2004.03.015

Baghalian, K., Ziai, S. A., Naghavi, M. R., Badi, H. N., \& Khalighi, A. (2005). Scientia Horticulturae, 103(2), 55-166. http://dx.doi. org/10.1016/j.scienta.2004.07.001

Chen, Z-Y., Jiao, R., \& Ma, K. Y. (2008). Review: cholesterol-lowering nutraceuticals and functional foods. Journal Agricultural and Food Chemistry, 56(19), 8761-8773. PMid:18778072. http://dx.doi. org/10.1021/jf801566r

Gómez, L. J. G., \& Sánchez-Muniz, F. J. (2000). Efectos cardiovasculares del ajo (Allium sativum L.). Archivos Latinoamericanos de Nutricion, 50(3), 219-229.

Holub, B. J., Arnott, K., Davis, J. P., Nagpurkar, A., \& Peschell, J. (2002). Organosulfur compounds from garlic. In J. Shi, G. Mazza \& M. L. Maguer (Eds.). Functional foods: biochemical and processing aspects (cap. 2, pp. 213-279). Washington: CRC Press.

Horwitz, W. (2010). Official methods of analysis of the AOAC (19th ed.). Gaithersburg: AOAC.

Hugues, J., Collin, H. A., Tregova, A., Tomsett, A. B., Cosstick, R., \& Jones, M. G. (2006). Effect of low storage temperature on some of the flavors precursors in garlic (Allium sativum L.). Plants Foods for Human Nutritional, 61, 81-85.

Jiménez-Monreal, A. M., García-Diz, L., Martínez-Tomé, M., Mariscal, M., \& Murcia, M. A. (2009). Influence of cooking methods on antioxidant activity of vegetables. Journal of food Science, 74(3), 97-103. PMid:19397724. http://dx.doi.org/10.1111/j.17503841.2009.01091.x

Lagunas, L. L. M., \& Castaigne, F. (2008). Effect of temperatura cycling on allinase activy in garlic. Food Chemistry, 111(1), 56-60. http:// dx.doi.org/10.1016/j.foodchem.2008.03.035

Lawson, L. D., Wang, Z. Y. J., \& Hugues, B. G. (1991). Identification and HPLC quantitation of the sulfides and dialk (en) yl thiosulfinates in commercial garlic products. Plant Medicine, 57(4), 363-370. PMid:1775579. http://dx.doi.org/10.1055/s-2006-960119

National Sanitation Foundation - NSF \& Internacional, Institute for Nutraceutical Advancement - INA. (2005). Allicin content in garlic by HPLC (INA method 110.001). Allicin by high-performance liquid chromatography. (INA Method 110.001). Retrieved from http:// www.nsf.org/business/ina/garlic.asp.

Okada, Y., Tanaka, K., Sato, E., \& Okajima, H. (2006). Kinetics and mechanistic studies of allicin as a antioxidant. Organic an Biomolecular Chemistry, 4(22), 4113-4117. http://dx.doi. org/10.1039/b611506c

Queiroz, Y. S., Ishimoto, E. Y., Bastos, D. H. M., Sampaio, G. R., \& Torres, E. A. F. S. (2009). Garlic (Allium sativum L.) and ready-toeat garlic products: in vitro antioxidant activity. Food Chemistry, 115(1), 371-374. http://dx.doi.org/10.1016/j.foodchem.2008.11.105

Queiroz, Y. S., Antunes, P. B., Vicente, S. J. V., Sampaio, G. R., Shibao, J., Bastos, D. H. M., \& Torres, E. A. F. (2014). Bioactive compounds, in vitro antioxidant capacity and Maillard reaction products of raw, boiled and fried garlic (Allium sativum L.). International Journal of Food Science \& Technology, 49(5), 1308-1314. http://dx.doi. org/10.1111/ijfs.12428

Kojuri, J., Vosouchi, A. R., \& Akrami, M. (2007). Effects of anethum graveolens and garlic on lipide profile in hyperlipidemic patients. Lipids and Health and Disease, 6, 1-5. PMid:17328819 PMCid:PMC1821028. http://dx.doi.org/10.1186/1476-511X-6-5

Rahman, K., \& Lowe, G. M. (2006). Garlic and cardiovascular disease: a critical review. Journal of Nutritional, 136(3 Suppl), 736S-704S. PMid:16484553.

Ribak, M. E., Calvey, E. M., \& Harnly, J. M. (2004). Quantitative determination of allicin in garlic: supercritical fluid extraction and standard addition of allin. Journal Agricultural and Food Chemistry, 52(4), 682-687. PMid:14969516. http://dx.doi.org/10.1021/ jf034853x

Statistical Analisys System Institute - SAS. (1993). SAS User's guide: statistics. Cary: SAS.

Silva, E. Y. Y., Moretti, C. L., \& Mattos, L. M. (2010). Compostos funcionais presentes em bulbilhos de alhos armazenados sob refrigeração, provenientes de cultivos no Brasil e na China. Ciência Rural, 40(12), 2580-2587. http://dx.doi.org/10.1590/S010384782010001200023

Sivam, G. P. (1997). Garlic and Helicobacter pylori. Food and Chemical Toxicology, 5(5), 582.

Tepe, B., Sokmen, M., Akpulat, H. A., \& Sokmen, A. (2005). In vitro antioxidant activities of the methanol extracts of five Allium species from Turkey. Food Chemistry, 92(1), 89-92. http://dx.doi. org/10.1016/j.foodchem.2004.07.016

World Health Organization - WHO (2010). WHO Monographs on medicinal plants commonly used in the Newly Independent States (NIS). Geneva: WHO Press. 450 p. 